\title{
Effect of serial photodynamic therapy with curcumin on Leishmania braziliensis and
}

\section{Leishmania amazonensis promastigotes}

\section{Efeito da terapia fotodinâmica seriada com curcumina em promastigotas de Leishmania braziliensis e Leishmania amazonensis}

Efecto de la fotodinámica serie con curcumina sobre Leishmania braziliensis y Leishmania amazonensis promastigotos

\author{
Lucas Tobias Rodrigues Maciel \\ ORCID: https://orcid.org/0000-0002-2906-6674 \\ University of Vale do Paraíba, Brazil \\ E-mail:1trmaciel@gmail.com \\ Luciana Maria Cortez Marcolino \\ ORCID: https://orcid.org/0000-0003-4305-8467 \\ University of Vale do Paraíba, Brazil \\ E-mail: lumaria.cortez@hotmail.com \\ Fernanda Bueno Sant'Anna Pereira Maciel \\ ORCID: https://orcid.org/0000-0003-2400-3815 \\ University of Vale do Paraíba, Brazil \\ E-mail: fernandabsp@gmail.com \\ Juliana Guerra Pinto \\ ORCID: https://orcid.org/0000-0002-7356-1576 \\ University of Vale do Paraíba, Brazil \\ E-mail: jgbiomd@gmail.com \\ Juliana Ferreira-Strixino \\ ORCID: https://orcid.org/0000-0001-7128-6817 \\ University of Vale do Paraíba, Brazil \\ E-mail: juferreira@univap.br
}

\begin{abstract}
Photodynamic Therapy (PDT) consists of using a light source and a photosensitive drug at an appropriate wavelength and molecular oxygen to trigger cell death through the production of reactive oxygen species. Because it is a localised therapy, PDT is shown to be ideal for skin diseases. American cutaneous Leishmaniasis (ACL) is a highly prevalent protozoan disease worldwide that presents different clinical evolutions and may result in ulcerations and disfiguring lesions on the skin and cartilage. This study was aimed at evaluating the effect in vitro of PDT applied serially using curcumin as a photosensitiser. For this, a concentration of $125 \mu \mathrm{g} \cdot \mathrm{mL}^{-1}$ of curcumin was used on Leishmania

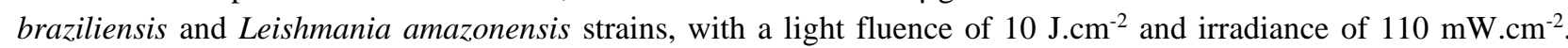
The tests done were viability analysis by trypan blue exclusion test, analysis of photosensitizer (PS) internalization by confocal microscopy and morphological alterations by May-Grunwald/Giemsa staining. We observed that there was internalisation of the PS before the first and second application of PDT, with L. braziliensis and L. amazonensis strains mortality of $92 \%$ and $82 \%$ respectively, after the second application, and induction of alterations in the structural conformation, such as cell size and non-evidence of nucleus and flagellum, demonstrating that PDT was effective. We conclude that serial PDT was effective in inducing the mortality of promastigotes forms of $L$. braziliensis and L. amazonensis in vitro, thus highlighting its potential for the treatment of Leishmaniasis.
\end{abstract}

Keywords: Photodynamic therapy; American Cutaneous Leishmaniasis; Curcumin.

\section{Resumo}

A terapia fotodinâmica (TFD) consiste no uso de uma fonte de luz e um fármaco fotossensível em um comprimento de onda adequado e oxigênio molecular para desencadear a morte celular por meio da produção de espécies reativas de oxigênio. Por ser uma terapia localizada, a TFD se mostra ideal para doenças de pele. A Leishmaniose Cutânea Americana (LCA) é uma doença protozoária de alta prevalência em todo o mundo que apresenta diferentes evoluções clínicas, podendo resultar em ulcerações e lesões desfigurantes na pele e cartilagem. Este estudo teve como objetivo avaliar o efeito in vitro da TFD aplicada em série usando a curcumina como fotossensibilizador. Para isso, foi utilizada uma concentração de $125 \mu \mathrm{g} \cdot \mathrm{mL}^{-1}$ de curcumina nas cepas de Leishmania braziliensis e Leishmania 
amazonensis, com fluência de luz de $10 \mathrm{~J} . \mathrm{cm}^{-2}$ e irradiância de $110 \mathrm{~mW} . \mathrm{cm}^{-2}$. Os testes realizados foram análise de viabilidade por teste de exclusão de azul de tripan, análise de internalização do fotossensibilizador (FS) por Microscopia Confocal e alterações morfológicas por coloração de May-Grunwald/ Giemsa. Observamos que houve internalização do FS antes da primeira e segunda aplicação da TFD, com mortalidade das cepas de L. braziliensis e $L$. amazonensis de $92 \%$ e $82 \%$ respectivamente, após a segunda aplicação, e indução de alterações na conformação estrutural, como tamanho da célula e não evidência de núcleo e flagelo, demonstrando que a TFD foi eficaz. Concluímos que a TFD seriada foi eficaz em induzir a mortalidade das formas promastigotas de L. braziliensis e L. amazonensis in vitro, destacando seu potencial para o tratamento da Leishmaniose.

Palavras-chave: Terapia fotodinâmica; Leishmaniose Cutânea Americana; Curcumina.

\section{Resumen}

La terapia fotodinámica (TFD) consiste en utilizar una fuente de luz y un fármaco fotosensible a una longitud de onda adecuada y oxígeno molecular para desencadenar la muerte celular mediante la producción de especies reactivas de oxígeno. Debido a que es una terapia localizada, se ha demostrado que la TFD es ideal para las enfermedades de la piel. La Leishmaniasis Cutánea Americana (LCA) es una enfermedad protozoaria de alta prevalencia a nivel mundial que presenta diferentes evoluciones clínicas y puede resultar en ulceraciones y lesiones desfigurantes en la piel y cartílago. Este estudio tuvo como objetivo evaluar el efecto in vitro de la TFD aplicada en serie utilizando curcumina como fotosensibilizador. Para ello, se utilizó una concentración de $125 \mu \mathrm{g} \cdot \mathrm{mL}^{-1}$ de curcumina en cepas de Leishmania braziliensis y Leishmania amazonensis, con una fluencia de luz de $10{\mathrm{~J} . \mathrm{cm}^{-2}}^{\mathrm{e}}$ irradiancia de $110 \mathrm{~mW} . \mathrm{cm}^{-2}$. Las pruebas realizadas fueron análisis de viabilidad mediante prueba de exclusión con azul tripán, análisis de la internalización del fotosensibilizador (FS) por microscopía confocal y alteraciones morfológicas mediante tinción de May-Grunwald/Giemsa. Observamos que hubo internalización del FS antes de la primera y segunda aplicación de TFD, con una mortalidad de las cepas de L. braziliensis y L. amazonensis del $92 \%$ y $82 \%$ respectivamente, después de la segunda aplicación, e inducción de alteraciones en la conformación estructural, como el tamaño de la célula y la ausencia de evidencia de núcleo y flagelo, lo que demuestra que la TFD fue eficaz. Concluimos que la TFD en serie fue eficaz para inducir la mortalidad de formas promastigotes de L. braziliensis y L. amazonensis in vitro, destacando así su potencial para el tratamiento de la Leishmaniasis.

Palabras clave: Terapia fotodinámica; Leishmaniasis Cutánea Americana; Curcumina.

\section{Introduction}

American Cutaneous Leishmaniasis (ACL) is a neglected, non-contagious infectious protozoa caused by different species of the genus Leishmania, and is a disease with disfiguring potential. Transmission occurs during blood repass of phlebotomine diptera, leading to clinical skin and mucosal manifestations (Sulaiman et al., 2019).

ACL is an endemic disease in more than 98 countries and it is estimated that 350 million people are exposed to the protozoan, with approximately two million new cases per year, becoming a serious public health problem (De Vries, Reedijk \& Schallig, 2015).

Among the most prevalent species inducing ACL is L. braziliensis belonging to the subgenus Viannia. This species is the most prevalent in humans and is responsible for the most aggressive cutaneous form among the other species, being present in all regions of Brazil. Among the subgenus species, Leishmania, L. amazonensis stands out, responsible for presenting all three forms of the disease (Silva et al., 2015; Andrade et al., 2018).

There is a shortage of available therapies for this disease, with pentavalent antimonials $\left(\mathrm{Sb} 5^{+}\right)$being considered the gold standard due to rapid kidney clearance and low tissue accumulation, but the need for successive parenteral administrations and the emergence of parasite resistance to these drugs have negatively influenced the evolution towards a cure prognosis (Aureliano et al., 2018), bringing to light the need for the introduction of secondary and auxiliary therapies, as a way to assist and expand the range of treatment for this protozoal disease (Torres-Guerrero et al., 2017).

Considered an obligate intracellular protozoan, innovative therapies, such as Photodynamic Therapy (PDT), have been promisingly highlighted as a less invasive, local treatment, providing a decrease in adverse reactions (Calvopiña et al., 2017). PDT is based on the excitation of a photosensitiser (PS) under exposure to light, interacting with molecular oxygen and inducing the formation of reactive oxygen species, among them singlet oxygen, promoting oxidative damage to biological substrates and inducing cell death (Berndt-Paetz et al., 2019; Gunaydin, Gedik \& Ayan, 2021). Curcumin is a substance 
commonly used as a food colourant and preservative, extracted from the powder of the turmeric or turmeric root (SuethSantiago et al., 2015; Yang et al., 2017). In addition to having therapeutic effects, curcumin has also been studied as a PS in PDT, showing great potential in in vitro studies against several species of Leishmania (Pinto et al., 2016).

In other ways, serial PDT (sPDT) has shown even more promise as it gives more effective results in achieving a cure

for leishmaniasis, as it consists of more than one application of the therapy (Johansen, Jernec \& Fabrícius, 2019; Goldin et al., 2020).

The aim of the current study was to evaluate the effect of serial photodynamic therapy using curcumin as a photosensitiser on Leishmania braziliensis and Leishmania amazonensis promastigotes.

\section{Methodology}

\section{Preparation of Leishmania culture}

Strains of Leishmania braziliensis (M2904) and Leishmania amazonensis (M2269) were kept in Liver Infusion Tryptose (LIT) culture medium supplemented with 10\% Fetal Bovine Serum, $2.5 \mu \mathrm{g} \cdot \mathrm{mL}^{-1}$ of hemin, $2 \%$ sterile urine and $1 \%$ penicillin/streptomycin solution. The protozoa were kept in an incubator at $26^{\circ} \mathrm{C}$ and maintenance replicates were performed weekly, after determining the logarithmic phase of growth of the strain.

\section{Determination of the growth curve of parasites in culture}

The determination of the stationary phase of parasite growth in culture was performed by means of daily counts of the protozoa, starting with $1 \times 10^{6}$ of the culture, a $10 \mu \mathrm{l}$ aliquot was withdrawn daily and transferred to $990 \mu \mathrm{l}$ of $1 \%$ paraformaldehyde solution. The total number of parasites counted in a with the aid of a Neubauer chamber and observation under a LEICA DM2500 microscope, for a period of 7 consecutive days.

\section{Preparation of photosensitiser}

Curcumin, the photosensitiser used in the study, was provided by the Laboratory of Biophotonics - Institute of Physics, University of São Paulo - São Carlos, and was initially diluted in DMSO (Dimethyl sulfoxide) (0.1\% of the final volume) and diluted with Phosphate Buffer Solution (PBS) at a concentration of $125 \mu \mathrm{g} \cdot \mathrm{mL}^{-1}$, which had already shown better results in viability testing with Trypan blue in a previous pilot study, conducted by the team of the Laboratory of Photobiology Applied to Health at the University of Vale do Paraíba - UNIVAP (Marcolino et al., 2021).

\section{Experimental procedure}

PDT was performed in two independent experiments, each in triplicate $(\mathrm{n}=6)$, with the Leishmania cultures in the stationary growth phase. The groups with $1 \times 10^{6}$ parasites were divided into: Control (no treatment), PS (treated with 125

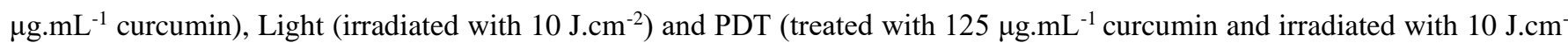
${ }^{2}$ ), divided into first and second application of PDT. PS and PDT groups were incubated with curcumin for one hour in an incubator at $26^{\circ} \mathrm{C}$.

For the irradiation of the Light and PDT groups using LED equipment, Biotable (450 nm, $110 \mathrm{~mW} . \mathrm{cm}^{-2}$, Biopdi®) was used for 91 seconds resulting in light fluence of $10 \mathrm{~J} . \mathrm{cm}^{-2}$ (Marcolino et al., 2021). After the process, the irradiated plates were stored, protected from light in an incubator at $26^{\circ} \mathrm{C}$ for a period of 48 hours, and the same procedure was applied to the dark groups. After this period, the second incubation and subsequent irradiation procedure was carried out with the same parameters, for a total of two applications. Analyses of internalisation, cell viability by Trypan blue exclusion test and morphology by May-Grunwald/Giemsa staining were carried out after the first and second applications, and the results were 
statistically evaluated and compared.

\section{Analysis of curcumin internalisation by Confocal Microscopy}

To check the internalisation of curcumin before the first application of PDT, both samples were incubated for 1 hour with PS at a concentration of $125 \mu \mathrm{g} \cdot \mathrm{mL}^{-1}$ (Pinto et al., 2016). After the incubation period, the medium containing PS was removed and the parasites were washed twice with PBS. The promastigotes were then fixed in $4 \%$ paraformaldehyde solution diluted in PBS and then adhered to circular coverslips treated with poly-L-lysine. The coverslips were mounted with ProLong ${ }^{\mathrm{TM}}$ Live Antifade Reagent (Thermofisher).

In addition, two groups of Leishmania strains that had previously undergone the first PDT application, received a new curcumin treatment and were subsequently fixed for internalisation analysis after 48 hours. The entire experimental procedure was carried out in the dark, and the slides were examined under a Zeiss LSM 700 confocal microscope, with excitation at 405 $\mathrm{nm}$ and emission above $500 \mathrm{~nm}$.

\section{Analysis of cell viability of promastigotes of $L$. braziliensis and $L$. amazonensis by the Trypan Blue exclusion method}

To determine the cell viability of the promastigotes of the strains evaluated, the Trypan Blue exclusion test was performed (Pinto et al., 2016). $10 \mu \mathrm{L}$ of the parasite culture was added to the Control group (no treatment), the PS group (treated with $125 \mu \mathrm{g} . \mathrm{mL}^{-1}$ of curcumin), the Light group (irradiated with $10 \mathrm{~J}^{\mathrm{cm}} \mathrm{cm}^{-2}$ ) and the PDT group (treated with 125 $\mu \mathrm{g} . \mathrm{mL}^{-1}$ of curcumin and irradiated with $\left.10 \mathrm{~J} . \mathrm{cm}^{-2}\right), 125 \mu \mathrm{g} \cdot \mathrm{mL}^{-1}$ of curcumin, for the PS and PDT groups and $90 \mu \mathrm{L}$ of Trypan blue for all the groups analysed. After homogenising and waiting for 5 minutes, the parasites were counted in a Neubauer chamber, determining the number of live and dead specimens. This procedure was also established in the groups submitted to the second application of PDT, being carried out in triplicate in both applications.

\section{Morphological analysis by May-Grunwald/Giemsa staining}

For morphological analysis, an aliquot from each group was taken and smears were prepared and then dried and stained. For May-Grunwald/Giemsa staining, the slide was covered with May-Grunwald stain for 1 minute. The same volume of water was then added, and removed after 1 minute.

Subsequently, the same volume of Giemsa stain, diluted in a Phosphate buffer, was added for 20 minutes. After 20 minutes, all excess dye was removed and the slides were washed in running water, dried and analysed using a LEICA DM 2500 microscope with a LEICA DFC 425 camera attached. This procedure was performed after the first and second PDT application.

\section{Statistical Analysis}

For statistical analysis, the data obtained was submitted to the One-way ANOVA test with the Tukey test as confirmation, using GraphPad Prism 6.0 software, with significance level $\mathrm{p}<0.0001$.

\section{Results}

\section{Determination of the stationary phase}

After performing the parasite growth curve for the 7 day period, it was observed that both species showed progressive growth, as expected (Figure 1). L. braziliensis (1.9 × $10^{6}$ - day 1), reached peak growth on day $5\left(94.2 \times 10^{6}\right)$, maintaining the plateau during day $6\left(93.4 \times 10^{6}\right)$, but with a small decrease in the number of parasites on day $7\left(92.7 \times 10^{6}\right)$. The species $L$. amazonensis $\left(1.1 \times 10^{6}\right.$ - day 1$)$, on the other hand, presented a growth peak on day $6\left(83.5 \times 10^{6}\right)$ and maintained the plateau 
on day $7\left(83.3 \times 10^{6}\right)$. After determining the stationary phase, the experiments were performed on day 5 for L. braziliensis and day 6 for L. amazonensis, as shown in Figure 1.

Figure 1. Growth curve of L. braziliensis and L. amazonensis for 7 consecutive days.

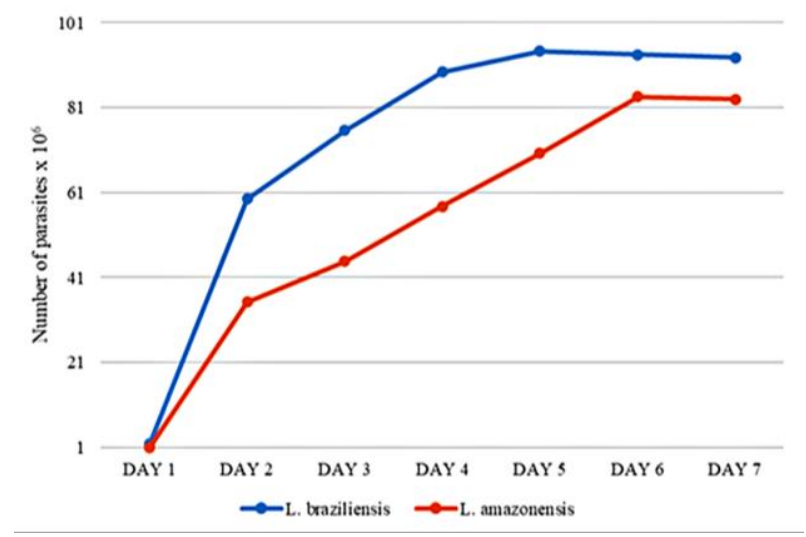

Source: Authors.

\section{Curcumin Internalisation}

Curcumin was observed after the first incubation to be present in the cytosol and flagella of both Leishmania species tested. In the analysis, after the second incubation with PS, it was possible to verify the presence of curcumin in the cytoplasm of both species, however, it was observed that there was a loss of the fusiform shape characteristic of the species and of a large part of the flagellum after the application of PDT, as demonstrated in figures A2 and B2 (Figure $2)$.

Figure 2. (A1) Presence of photosensitiser inside L. amazonensis after the first incubation, being 1 - Flagellum and 2 Cytoplasm (A2) L. amazonensis after the second incubation, with presence of curcumin inside the cytoplasm and low fluorescence in the flagellum. (B1) Curcumin present in flagella (1) and cytoplasm (2) of L. braziliensis after first incubation. (B2) L. braziliensis after second incubation, showing cytoplasm, with low fluorescence in the flagellum.
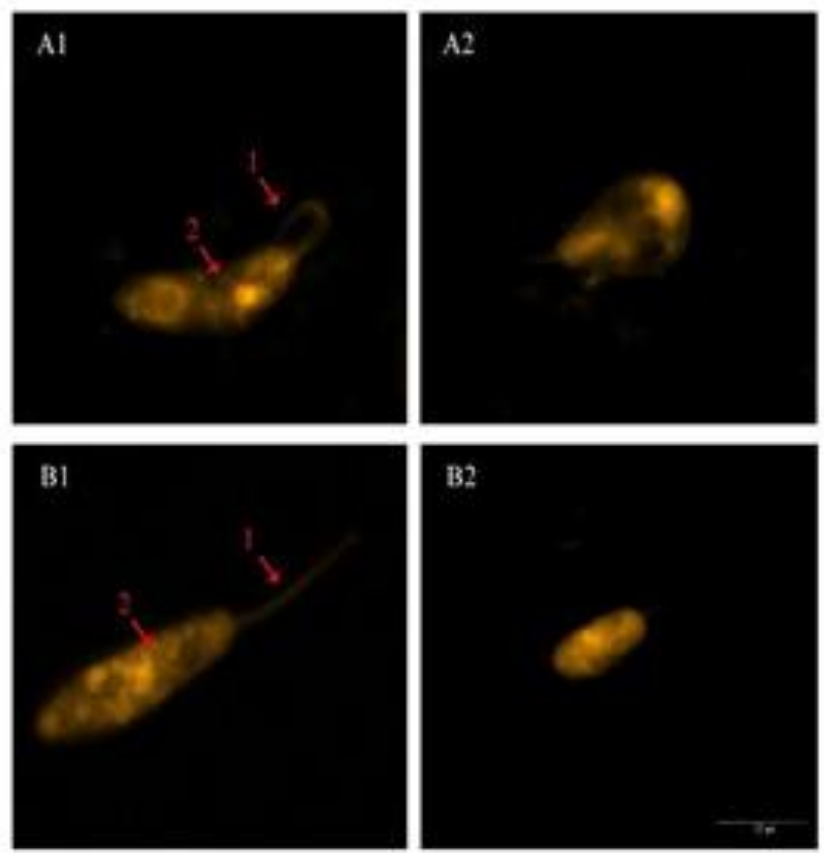

Source: Authors. 


\section{Analysis of cell viability of $L$. braziliensis and $L$. amazonensis promastigotes by Trypan blue exclusion test}

After performing the serial PDT treatment with curcumin, the viability test demonstrated that the Dark groups (Control and $125 \mu \mathrm{g} \cdot \mathrm{mL}^{-1}$ ) as well as the Light treatment did not show impact on the viability of L. braziliensis species confirming absence of toxicity of curcumin and light in isolation to the cell.

The PDT group showed high cell toxicity, with a significant difference $(\mathrm{p}<0.0001)$ in relation to the control group, obtaining a mortality rate of $68 \%$ and $92 \%$ after the first and second application of therapy, respectively (Figure 3).

Figure 3. Percentage of viable L. braziliensis promastigotes: first and second applications of PDT with curcumin at a concentration of $125 \mu \mathrm{g} \cdot \mathrm{mL}^{-1}$.

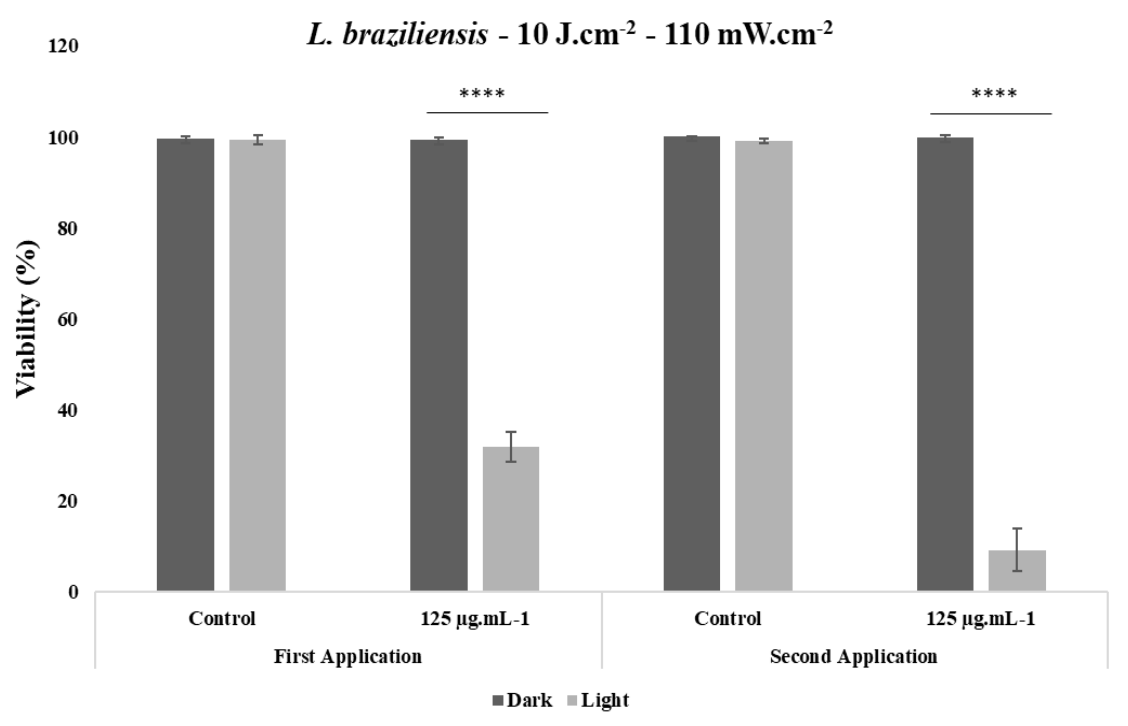

Source: Authors.

Figure 4. Percentage of viable L. amazonensis promastigotes: first and second applications of PDT with curcumin at a concentration of $125 \mu \mathrm{g} \cdot \mathrm{mL}^{-1}$.

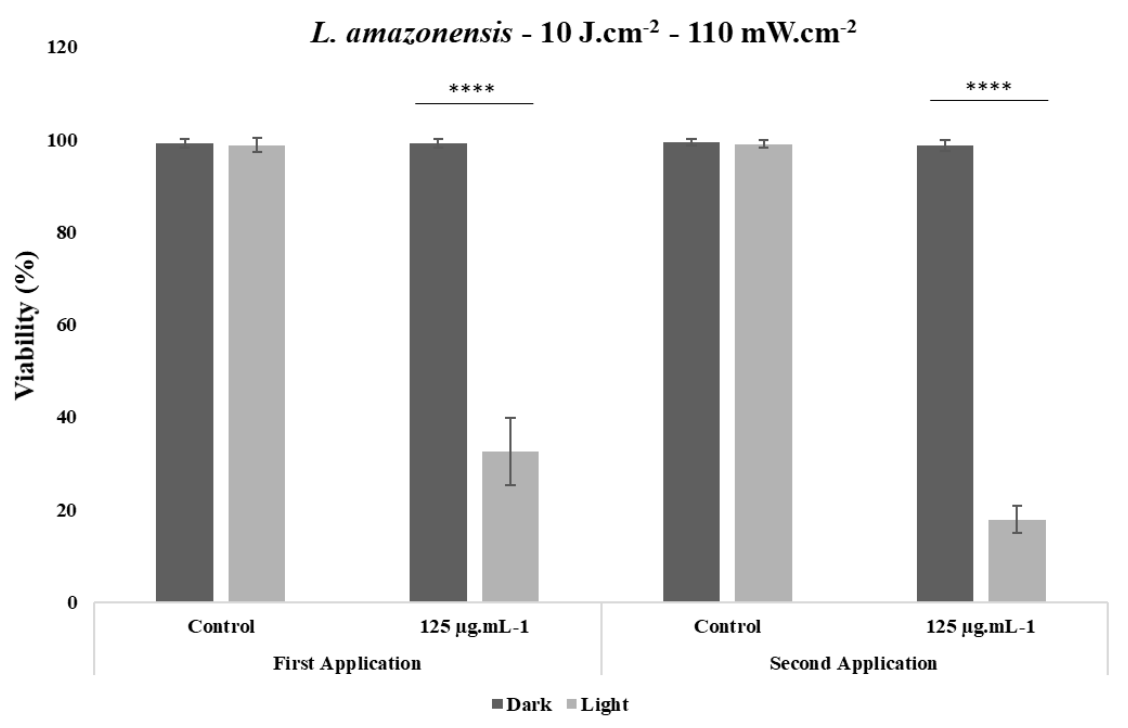

Source: Authors. 
The L. amazonensis species showed similar results to those observed in L. braziliensis, so that the Dark and Light groups showed no statistically significant difference, but the PDT group showed high toxicity when compared to the group incubated with only $125 \mu \mathrm{g} \cdot \mathrm{mL}^{-1}$ of curcumin, obtaining a mortality rate of $67 \%(\mathrm{p}<0.0001)$ after the first application of PDT and $82 \%(\mathrm{p}<0.0001)$ in the second application (Figure 4$)$.

\section{Morphological analysis of promastigotes after repeated treatment with curcumin}

In general, the morphological analysis of L. braziliensis and L. amazonensis, revealed that the Dark groups (Control and $125 \mu \mathrm{g} . \mathrm{mL}^{-1}$ ) and the Light group showed no visible morphological changes, maintaining fusiform appearance, with nucleus, kinetoplast and flagellum evident.

After the first and second application of PDT, the parasites showed significant morphological changes when compared to the other untreated groups, with a general decrease in cytoplasm, alteration of the fusiform shape and, in some cases, absence of flagella.

Figure 5. Morphology of L. braziliensis in all experimental groups, dark and light at a fluence of $10 \mathrm{~J} . \mathrm{cm}^{-2}-110 \mathrm{~mW} . \mathrm{cm}^{-2}$, after two applications of PDT.

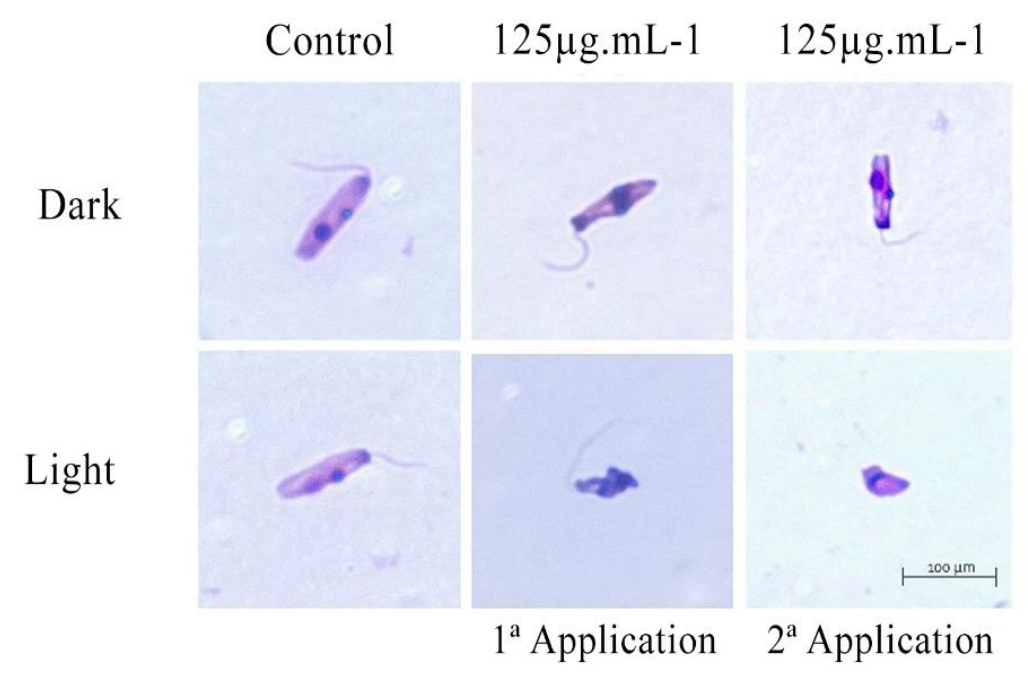

Source: Authors.

Concerning the morphology of L. braziliensis (Figure 5) there was a change in the fusiform aspect and in the size of the parasite after the first application of PDT, however the strain still showed evident flagella. Regarding the organelles present in the cytoplasm, the presence of the nucleus and kinetoplast can still be observed. After the second application, a more accentuated decrease and more evident alterations to the original shape of the protozoan were observed. As far as structures are concerned, the flagellum was not evident, with evidence only of the nucleus.

In the analyses performed with the L. amazonensis strain (Figure 6), the morphological alterations were even more evident than those observed in the L. braziliensis strain.

After the first application of PDT on L. amazonensis strains, an alteration in their structure was observed, with loss of the elongated and fusiform shape; however, the nucleus and flagellum were evident. After the second application of PDT, the 
absence of nucleus and kinetoplast was observed. With regard to the shape, there was an even more accentuated change, as it went from a large elongated and fusiform shape to a small and rounded one.

Figure 6. Morphology of L. amazonensis in their respective experimental groups, dark and light at a fluence of $10{\mathrm{~J} . \mathrm{cm}^{-2}}^{2}$ and $110 \mathrm{~mW} . \mathrm{cm}^{-2}$ after two applications of PDT.

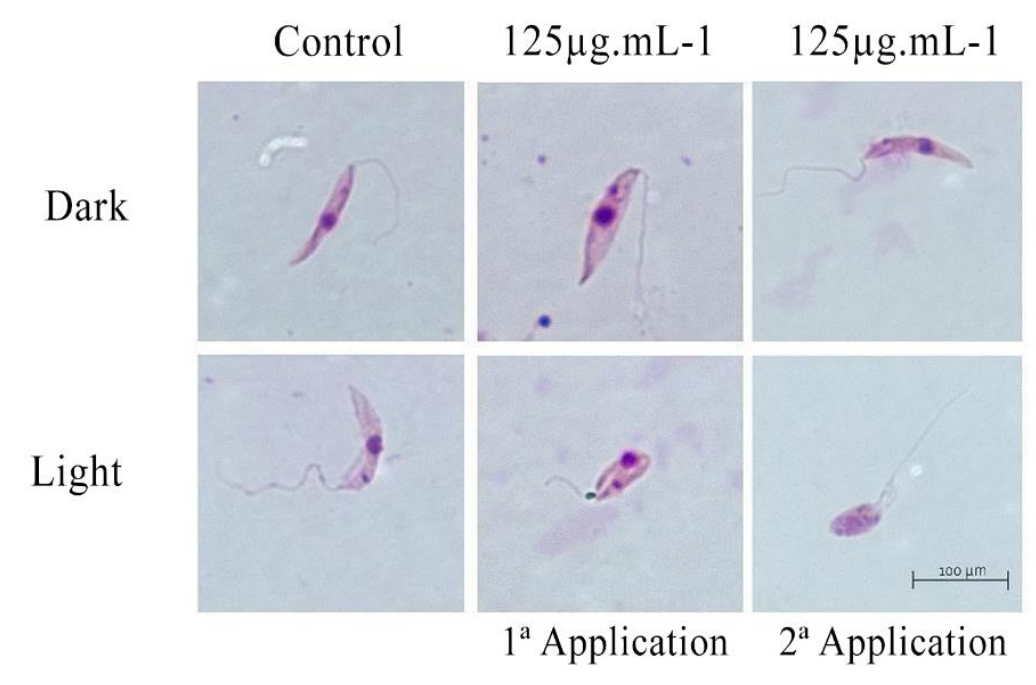

Source: Authors.

\section{Discussion}

In the present work we observed that curcumin was internalised in L. braziliensis and L. amazonensis species promastigotes at the two observed time points, namely first and second incubation. Such results corroborate those presented by Pinto et al. (2016), who demonstrated curcumin's internalisation capacity by promastigotes of L. braziliensis and L. major after one hour of incubation, showing a diffuse distribution in the cytosol, with specific accumulation in the nucleus and kinetoplast. One of the aims of this study was to assess whether after an application of PDT, there were still viable cells that might again be able to internalise the PS and, consequently, be amenable to elimination after a second application of PDT. The results obtained not only allowed the observation of PS internalisation after the first application of PDT, but also showed the efficiency of the second application of PDT, demonstrating greater morphological changes and viability of promastigote shapes.

Since the observation of curcumin internalisation was only qualitative, by visual evidence under a confocal microscopy, it was not possible to infer the existence or not of quantitative differences in PS internalisation. This would be possible by the use of techniques with greater accuracy beyond simple visualisation, such as, for example, induction of parasite rupture with release of their intracellular contents and subsequent determination of the amount of PS by using spectrophotometry (Akilov et al., 2007).

Indeed, internalisation efficacy is one of the fundamental factors for the success of PDT so that if viable cells persist after a first application of PDT, the success of further internalisation of the PS would be critical for the efficacy of a second application. In this regard, the damage resulting from the first application of PDT may have been crucial not only to induce the death of promastigote shapes but also to cause morphological changes in the forms that survived, and consequently to allow a 
persistence or even an increase in PS internalisation for subsequent applications, and consequently an increase in the efficacy of the therapy.

The efficacy of curcumin as a PS is possibly related to the capacity of this molecule to induce oxidative stress in photodegradation experiments, with production of ROS, more specifically singlet oxygen, hydrogen peroxide and hydroxyl radicals, boosting the bioavailability of such substances, which would possibly culminate in a collapse in the capacity of resistance to ROS that the parasite commonly presents, thus making it more susceptible to being eliminated (Kazantzis et al., 2020).

In fact, to maintain the longevity of a parasitic cell, it is of fundamental importance that this cell maintains cellular homeostasis against ROS, and when a cell fails to maintain its homeostasis by using its antioxidant capacity, oxidative stress is generated, which leads to apoptosis. Thus, to protect itself from ROS mediated apoptosis, the parasite must strictly control the levels of such substances in order to positively regulate antioxidant defence (Ha et al., 1998). With the increased availability of ROS induced by PDT using curcumin as PS, this balance tends to break down unfavourably for the parasite, extrapolating its ability to clear ROS, and consequently leading it to death (Mandal et al., 2016). ROS plays an important role in the defence against Leishmania, but the parasite has arsenals of defence in order to survive without being destroyed by such molecules. According to Marcolino et al. (2021), ROS, when produced in excess, are capable of inducing DNA, protein and lipid damage, and thus cause the cell death of various pathogens, including species of the genus Leishmania. In contrast, these protozoa are able to evade the action of ROS mainly by deregulating enzymes involved in the production of such molecules, as well as by negatively regulating their production at mitochondrial level. These authors emphasise the potential for the use of compounds that generate ROS as tools for the development of new therapeutic strategies for the control of leishmaniasis, and in this case, the potential of the therapy proposed in this work, the PDT using curcumin as a photosensitiser, can be highlighted.

It should be noted that only promastigotes were used in the experimental procedures in this study. Although such evolutive forms are not present in the lesion of a patient diagnosed with leishmaniasis, a fact that could limit the relevance of any possible result of in vitro efficacy, according to Van Assche et al. (2011), the fact that a therapy based on ROS production is efficient in inducing the mortality of promastigotes is of great importance, since these parasitic forms are capable of producing high amounts of antioxidant enzymes against ROS, and such capacity is maintained in the progression to the amastigote condition, although possible adjustments in the concentration/dose of PS and light are necessary when using amastigotes, as reported by Pereira et al. (2021).

According to Cabral et al. (2020) the antioxidant patterns of Leishmania are essential for drug resistance, relapse and pathogenicity, and thus more intense oxidative damage induced by PDT may cause the destruction of the parasite.

Kocyigit \& Guler (2017) demonstrated curcumin's capacity to induce oxidative stress and showed its potential use for cancer treatment, inducing, in vitro, DNA damage in murine melanoma B16-F10 cells, as well as apoptosis and cytotoxicity via its pro-oxidant activity, but this capacity is dose-dependent. In this study, treatment with curcumin alone at the concentration applied was not able to induce perceptible damage to the promastigotes of the parasite and consequently did not affect its viability, but its pro-oxidant activity was maximised not by increasing the concentration of PS, but by PDT or more precisely by sPDT (Serial Photodynamic Therapy).

With respect to the morphology of the strains studied, both demonstrated changes in the groups in which PDT was applied when compared to the dark groups. The groups irradiated with $125 \mu \mathrm{g} \cdot \mathrm{mL}^{-1}$ of curcumin showed relevant morphological alterations since the first application, being possible to observe loss of fusiform shape and flagellum in $L$. braziliensis strains, but the nucleus was still evident in the two applications. However, in the L. amazonensis strains, it can be observed that in comparison with the other strain studied, the alterations were even more accentuated, as in a second application, besides losing the fusiform shape and presenting a rounded shape, the nucleus was not evident. 
According to Basmaciyan \& Casanova (2019), for apoptosis to be defined in Leishmania several criteria must be considered, and, in relation to morphology at least two of the following five alterations must be present: cell shrinkage, cell rounding, alterations in the plasma membrane with the maintenance of its integrity, nuclear fragment and chromatin condensation. By means of the experimental procedures outlined in this study it was possible to identify cell shrinkage and rounding in the two Leishmania species evaluated, thus suggesting that the use of PDT, more precisely sPDT was able to cause irreversible damage to the structure of these protozoa, probably by inducing apoptosis.

Also, according to Basmaciyan \& Casanova (2019), the induction of oxidative stress with production of ROS promotes stimuli that induce phenotypes similar to apoptosis. These morphological changes were also reported in a study with curcumin and using fluence of $10 \mathrm{~J} . \mathrm{cm}^{-2}$ carried out by Pinto et al. (2016). This study confirms the current findings, as there were also alterations in their morphology with the loss of the spindle shape, as well as the absence of kinetoplast and flagella in L. braziliensis and L. major strains.

The morphological changes proved to be different, such discrepancies possibly being due to structural peculiarities of each Leishmania species, which show particularities in their structure, as described by Sunter \& Gull (2017). These researchers demonstrated that the cell membrane of this protozoan has microtubules, which, besides helping in the fusiform shape, also help in protection, preventing some foreign substances from being absorbed. However, these authors do not infer any structural difference of microtubules in different species of Leishmania.

Dubey \& Chinnatahambi (2021) stated, based on scientific evidence from several researchers, that PDT modulates the structural dynamics of the cytoskeleton of several cell lines, and may induce disruption of the tubulin network and intermediate filaments in tumor cells, as well as changes in the organisation and disruption of the actin cytoskeleton, disorganisation of the microtubules of cells, increase in intracellular calcium, which leads to depolymerisation of microtubules, besides the induction of a large number of small cytoplasmic invaginations on the cell surface, possibly as a function of depolymerisation of microtubules. According to these authors, microtubules are part of the cellular cytoskeleton and can be targeted by PDT. Taking into consideration the importance of microtubules in maintaining the fusiform structure and in limiting the internalisation of molecules, it can be implied that the morphological changes demonstrated here may be consequent to the induction of damage to microtubules, arising from the use of PDT using curcumin as PS.

As already explained, the efficacy of only one PDT application was $68 \%$ for the L. braziliensis species and $67 \%$ for the L. amazonensis, as confirmed by the Trypan blue exclusion viability test. Such results corroborate the results of Pinto et al. (2016), however, the authors used only one application of the therapy and obtained promising results, with about 80\% reduction of viability, these values being close to those obtained when the first application of PDT was used. However, in this study a second application of PDT was carried out, characterising the so called Serial Photodynamic Therapy, reaching higher mortality rates in both species of Leishmania evaluated, with an increase in mortality from $68 \%$ to $92 \%$ in strains of $L$. braziliensis and $67 \%$ to $82 \%$ in strains of L. amazonensis. This is consistent with the findings of some researchers (Johansen, Jemec \& Fabrícius, 2019; Goldin et al., 2020), who demonstrated better performance of sPDT, including the design of experiments, for the treatment of patients affected by leishmaniasis.

\section{Conclusion}

Based on the results obtained, it can be concluded that PDT with curcumin, in the protocol tested, demonstrated effectiveness, in vitro, against promastigotes of L. braziliensis and L. amazonensis, with improved efficacy when compared to the results of induction of morphological changes and mortality obtained after only one application of PDT.

Despite the promising results here, the non-induction of $100 \%$ mortality of Leishmania strains submitted to two applications of PDT, allows us to suggest the demand for new experimental protocols, aiming to obtain a greater effectiveness 
in inducing mortality when using more than two applications of the therapeutic scheme proposed in the present study.

The next works will involve the analysis of macrophages infected with amastigote forms, to assess the serial PDT response and the main cellular mechanisms involved.

\section{Acknowledgments}

The authors would like to thank the Research and Development Institute of the University of Vale do Paraíba. This research was funded by São Paulo State Research Support Foundation (FAPESP), grant number 2016/12211-4, FINEP, grant number 01.13.0275/00, and Coordination for the Improvement of Higher Education Personnel—Brazil (CAPES), grant number Code 001.

\section{References}

Andrade, C. G. et al. (2018). Photodynamic effect of zinc porphyrin on the promastigote and amastigote forms of Leishmania braziliensis. Photochemical \& Photobiological Sciences, 17(4), 482-490.

Akilov, O. E. et al. (2007). Parasiticidal effect of- delta-aminolevulinic acid-based photodynamic therapy for cutaneous leishmaniasis is indirect and mediated through the killing of the host cells. Experimental Dermatology, 16, 651-660.

Anversa, L. et al. (2017). Human leishmaniasis in Brazil: A general review. Rev. Assoc. Med. Bras, 64(3), 281-289.

Alvar, J. et al. (2012). Leishmaniose mundial e estimativas globais de sua incidência. PLoS One, 7(5). e35671.

Aureliano, D. P. et al. (2018) Cell death mechanisms in Leishmania amazonensis triggered by methylene blue mediated antiparasitic photodynamic therapy, Photodiagnosis and Photodynamic Therapy, 23, 1-8.

Basmaciyan, L. \& Casanova, M. (2019) Cell death in Leishmania. Parasite, 26, 71.

Berndt-Paetz, M. et al. (2019). Reduction of muscle-invasive tumors by photodynamic therapy with Tetrahydroporphyrin-Tetratosylat in an orthotopic rat bladder cancer model. Molecular Cancer Therapeutics, 3, 1-22.

BRASIL - Portal MS - Ministério da Saúde. Disponível em: www.gov.br/saude/pt-br/assuntos/saude-de-a-a-z-1/1/leishmaniose-visceral. Acesso em: mar 2021.

Cabral, F. V. et al. (2020). Preclinical Investigation of Methylene Blue-mediated Antimicrobial Photodynamic Therapy on Leishmania Parasites Using RealTime Bioluminescence. Photochemistry and Photobiology, 96, 604-610.

Calvopiña, M. et al. (2017). Intralesional Infiltration with Meglumine Antimoniate for the Treatment of Leishmaniasis Recidiva Cutis in Ecuador. Am. J. Trop. Med. Hyg, 97(5), 1508-1512.

De Vries, H. J. C. Reedijk, S. H. \& Schallig, H. D. F. H. (2017). Cutaneous Leishmaniasis: Recent Developments in Diagnosis and Management. Am. J. Clin. Dermatol, 16, 99-109.

Dubey, T. \& Chinnathambi, S. (2021). Photodynamic sensitizers modulate cytoskeleton structural dynamics in neuronal cells. Cytoskeleton, $2021,1-17$.

Fakhar-E-Alam, M. et al. (2017). Empirical modeling of physiochemical imune response of multilayer zinc oxide nanomaterials under UV exposure to melanoma and foreskin fibroblasts. Scientific Reports, 7, 1-13.

Goldin, H. et al. (2020). Leishmania tropica infection of the ear treated with photodynamic therapy. JAAD Case Reports, 6, 514-517.

Ha, H. C. et al. (1998). The natural polyamine spermine functions directly as a free radical scavenge. Proc. Natl. Acad. Sci, $95,11140-11145$.

Johansen, B. Jemec, G. B. E. \& Fabricius, S. (2019). Effective treatment with photodynamic therapy of cutaneous leishmaniasis: A case report Mila. Dermatologic Therapy, 32, 1-6.

Kazantzis, K. T. et al. (2020). Curcumin derivatives as photosensitizers in photodynamic therapy: photophysical properties and in vitro studies with prostate cancer cells. Photochemical \& Photobiological Sciences, 19, 193-206.

Kocyigit, A. \& Guler, E. M. (2017). Curcumin induce DNA damage and apoptosis through generation of reactive oxygen species and reducing mitochondrial membrane potential in melanoma cancer cells. Cellular and Molecular Biology, 63(11), 97-105.

Lei, S. et al. (2021). Photodynamic therapy with curcumin for combating SARS-CoV-2. Photodiagnosis and Photodynamic Therapy, $34,102284$.

Mandal, A. et al. (2016). Deprivation of L-Arginine induces oxidative stress mediated apoptosis in Leishmania donovani promastigotes: Contribution of the polyamine pathway. PLOS Neglected Tropical Diseases, 10(1), e0004373.

Marcolino, L. M. C. Pereira, A. H. C. Pinto, J. G. Mamone, L. A. \& Ferreira-Strixino, J. (2021). Cellular and metabolic changes after photodynamic therapy in Leishmania promastigotes. Photodiagnosis and Photodynamic Therapy, 35, 102403. 
Research, Society and Development, v. 10, n. 11, e219101119544, 2021

(CC BY 4.0) | ISSN 2525-3409 | DOI: http://dx.doi.org/10.33448/rsd-v10i11.19544

Pereira, A. H. C. Marcolino, L. M. C. Pinto, J. G. \& Ferreira-Strixino, J. (2021). Evaluation of the Photodynamic Therapy with Curcumin on L. braziliensis and L. major amastigotes. Antibiotics, 10(6), 634.

Pinto, J. G. et al. (2016). In vitro evaluation of photodynamic therapy using curcumin on Leishmania major. Lasers in Medical Science, 31(5), 883-890.

Silva, E. P. O. et al. (2015). Photodynamic effects of zinc phthalocyanines on intracellular amastigotes of Leishmania amazonensis and Leishmania braziliensis. Lasers in Medical Science, 30, 347-354.

Sueth-Santiago, V. Mendes-Silva, G. P. Decote-Ricardo, D. \& Lima, M. E. F. (2015). Curcumin, the golden powder from turmeric: insights into chemical and biological activities. Quím. Nova, 38(4), 538-552.

Sulaiman, A. A. et al. (2019). An outbreak of cutaneous leishmaniasis among a displaced population in North Sudan: Review of cases. J. Family Med. Prim. Care, 8(2), 556-563.

Sunter, J. G. K. \& Gull, K. (2017). Shape, form, function and Leishmania pathogenicity: from textbook descriptions to biological understanding. Open Biol, 8(8), 1-11.

Torres-Guerrero, E. Quintanilla-Cedillo, M. R. Ruiz-Esmenjaud, J. \& Arenas, R. (2017). Leishmaniasis: A Review. F1000Res, $26(6), 750$.

Van Assche, T. et al. (2011). Leishmania macrophage interactions: insights into the redox biology. Free Radical Biology and Medicine, 51(2), 337-351.

Yang, D. Li, Y.\& Zhao, D. (2017). Curcumin induces apoptotic cell death in human pancreatic cancer cells via the miR-340/ZIAP signaling pathway. Oncology Letters, 14, 1811-1816. 